mold Physarum polycephalum during differentiation. J Cell Phvsiol 125:413419

31. Allen RG. Balin AK. Reimer RJ. Sohal RS. Nations C 1988 Superoxide dismutase induces differentiation in microplasmodia of the slime mold Physarum polycephalum. Arch Biochem Biophys 261:205-2! I

32. Beckman BS, Balin AK. Allen RG 1989 Superoxide dismutase induces differentiation of Friend erythroleukemia cells. J Cell Physiol 139:37()-376

33. Allen RG, Oberley LW. Elwell JH. Sohal RS 1991 Developmental patterns in the antioxidant defences of the housefly, Musca demestica. J Cell Physiol
$146: 270-276$

34. Oberley TD, Oberley I.W. Slattery AF. Lauchner LJ. Elwell JH 1990 lmmunohistochemical localization of antioxidant enzymes in adult Syrian hamster tissues and during kidney development. Am J Pathol 137:199-214

35. Oberley TD. Oberley LW. Slattery AF. Elwell JH 1991 Immunohistochemical localization of glutathione-S-transferase and glutathione peroxidase in adult Syrian hamster tissues and during kidney development. Am J Pathol $139: 355-369$

\title{
Announcement
}

\section{Paediatric Week Holland}

The Paediatric Week Holland will be organized in Rotterdam. The Netherlands from June 29 to July 6, 1994. From July 3 through July 6 , a combined meeting will be held of the European Society for Paediatric Research, the European Paediatric Respiratory Society, the European Respiratory Society-Paediatric Assembly, the European Society of Paediatric Allergy/Clinical Immunology, the European Society for Paediatric Infectious Diseases, the European Society of Paediatric Intensive Care, and the European Society for Paediatric Hematology and Immunology. From June 29 through July 2, the British Association of Paediatric Surgeons will meet, and the Dutch Society of Psychosocial Consultation and Paediatrics will meet from July 3 through July 5. Postgraduate courses will be organized in the overlapping weekend. For further information. please contact: Pieter J. J. Sauer, M. D., c/o Erasmus University Rotterdam, P.O. Box 1738, NL-3000 DR Rotterdam. The Netherlands. 